Received Date : 15-Mar-2013

Revised Date : 21-Oct-2013

Accepted Date : 29-Oct-2013

Article type : Symposium Article

Heger et al. --- Importance of Field Protistology

\title{
A Resurgence in Field Research is Essential to Better Understand the Diversity, Ecology, and Evolution of Microbial Eukaryotes
}

Thierry J. Heger ${ }^{\mathrm{a}}$, Virginia P. Edgcomb ${ }^{\mathrm{b}}$, Eunsoo Kim ${ }^{\mathrm{c}}$, Julius Lukeš ${ }^{\mathrm{d}}$, Brian S. Leander ${ }^{\mathrm{a}}$ \& Naoji Yubuki $^{\mathrm{a}}$

a The Departments of Botany and Zoology, Beaty Biodiversity Research Centre and Museum, University of British Columbia, Vancouver, British Columbia, V6T 1Z4, Canada

${ }^{\mathrm{b}}$ Woods Hole Oceanographic Institution, Geology and Geophysics Department, Woods Hole, MA 02543, USA

${ }^{c}$ Division of Invertebrate Zoology, American Museum of Natural History, New York, NY, 10024, USA

d Institute of Parasitology, Biology Centre, Czech Academy of Sciences, and Faculty of Science, University of South Bohemia, 37005 České Budějovice, Czech Republic

\section{Correspondence}

T. J. Heger and N. Yubuki, The Departments of Botany and Zoology, Beaty Biodiversity Research Centre and Museum, University of British Columbia, 6270 University Blvd., Vancouver, British Columbia, V6T 1Z4, Canada

Telephone number: +1 604822 4892; FAX number: +1 604822 6089; emails: thierry.heger@botany.ubc.ca and yubuki@mail.ubc.ca

\section{ABSTRACT}

The discovery and characterization of protist communities from diverse environments are crucial for understanding the overall evolutionary history of life on earth. However, major questions about the diversity, ecology, and evolutionary history of protists remain unanswered, notably because data obtained from natural protist communities, especially of heterotrophic species, remain limited. In this review, we discuss the challenges associated with "field protistology", defined here as the exploration, characterization, and interpretation of microbial eukaryotic diversity within the context of natural environments or field experiments, and provide

This article has been accepted for publication and undergone full peer review but has not been through the copyediting, typesetting, pagination and proofreading process, which may lead to differences between this version and the Version of Record. Please cite this article as doi:

10.1111/jeu.12095-4379

This article is protected by copyright. All rights reserved. 
suggestions to help fill this important gap in knowledge. We also argue that increased efforts in field studies that combine molecular and microscopical methods offer the most promising path toward (1) the discovery of new lineages that expand the tree of eukaryotes; (2) the recognition of novel evolutionary patterns and processes; (3) the untangling of ecological interactions and functions, and their roles in larger ecosystem processes; and (4) the evaluation of protist adaptations to a changing climate.

Keywords Algae; culture; field research; food webs; microscopy; molecular phylogenetics; protist; protozoa.

FIELD studies since the 1600's form the foundation for exploratory research in protistology. The pioneering work by Antoni van Leeuwenhoeck (1632-1723), Louis Joblot (1645-1723), and Otto Müller (1730-1784) advanced light microscopy which allowed the first discoveries of microscopic protists (Dobell 1923; Lechevalier 1976). Joblot's drawings of protozoa reflected the uniqueness of the organisms he was observing (Fig. 1), and Müller produced the first book dedicated to protists, Animalcula Infusoria (Müller 1786). In the 1800's, great improvements to microscope lenses occurred and during that time Christian Gottfried Ehrenberg (1795-1876), Edouard Claparède (1832-1871), Ernst Haeckel (1834-1919), Georg Klebs (1857-1918) and others contributed incredibly detailed and beautiful drawings of many free-living protists. Foraminifera were first recognized as protists by Félix Dujardin in 1835, and Alcide d'Orbigny produced the first classifications that were expanded upon by foraminferologists such as Henry Brady (1835-1891) who worked on seafloor sediment samples from the HMS Challenger cruise in 1872, the first scientific cruise to sample the ocean floor (Brady 1876). The naturalists Joseph Leidy (1823-1891) and Eugène Penard (1855-1954) described and illustrated dozens of new amoebae species from freshwater and soil habitats. In the 1900's, Heinrihs Skuja (1892-1972), Alfred Kahl (1877-1946) and many others made numerous remarkable observations of protists, particularly from oxygen-depleted environments. This rich legacy in protistology has been expanded upon by numerous "field protistologists", many of whom made major contributions during the $20^{\text {th }}$ century, and continue to do so today.

The purpose of this review is to (1) highlight how field work in protistology provides important insights into fundamental questions in biology, (2) evaluate why data from the field tend to be limited for protists, and (3) draw attention to several challenges associated with the future of field protistology. Here, we define "field protistology" as the exploration, characterization and interpretation of microbial eukaryotic diversity within the context of natural environments or field experiments. Although we think that the data from the field is relatively limited for protists, we fully recognize that the studies performed in the field so far have significantly improved our understanding of microbial eukaryotic diversity.

\section{The importance of protistan fieldwork Protists are understudied in comparison to plants, animals, or fungi}

Despite numerous field studies since the $17^{\text {th }}$ century, protists remain the least explored eukaryotic component of the biosphere. Major questions about the diversity, ecology, and evolutionary history of these organisms remain unanswered, largely because data obtained from the field are limited. The extent of our ignorance about protistan diversity is notably illustrated

This article is protected by copyright. All rights reserved. 
by the important discrepancy between the actual number of described species and the overall estimated number of protist species. For instance, it is thought that the photosynthetic protists Bacillarophyta comprises about 200,000 taxa but only a tenth of its diversity has been described (i.e., only 10,000 to 20,000 species) (Mann and Droop 1996, Norton et al. 1996). Similarly, only 3,500 ciliate taxa out of a total of 30,000 estimated species have been described but the biggest gap is certainly found in parasites like apicomplexans where out of an estimated number of 1.2 10 million species, only 6,000 species have been described (Adl et al. 2007). The recognition of protist species is dependent on the kind of data used to characterize them; for instance, species recognized solely on the basis of morphological traits may be either an underestimation or an overestimation of species recognized with molecular phylogenetic data. Therefore, estimates for the total number of species in different groups of protists are not necessarily comparable and are limited by available data and the way these data are interpreted by different protistologists (Boenigk et al. 2012). Even though it is important to treat species estimates with caution, there is a strong consensus among protistologists that there is a significant gap between the actual number of described protist species and the total number of protist species on Earth.

In molecular barcode reference libraries, protists are also underrepresented compared to other groups of organisms. Fortunately, ambitious projects like the Protist Ribosomal Reference Database (Guillou et al. 2013), the AlgaeBase (Guiry and Guiry 2013) or the Protist Working Group (Pawlowski et al. 2012) of the Consortium for the Barcode of Life (CBOL, http://www.barcodeoflife.org) will undoubtedly facilitate the development of a protistan reference barcode library and, thus, help to characterize protistan diversity at fine taxonomic scales. In terrestrial and aquatic ecology, protists have also received relatively little attention compared to other groups of organisms. For instance, they are generally not integrated in the Long Term Ecological Research (LTER) Network experiments, which aim to address important questions about the impacts of lake acidification, climate change or diversity loss (Knapp et al. 2012) (http://www.lternet.edu/). Neglecting protistan communities in these experiments and other studies might seriously bias our general understanding of food web processes and biogeochemical cycles.

Protists are also poorly studied across space and time, and therefore, several fundamental questions in protistology cannot be fully addressed. At a global scale, no or few protist biodiversity surveys have been conducted in several regions on the planet, especially in environments outside Europe and North America (Adl et al. 2007). Thus, the distribution of free living protists has been a contentious issue between two opposing views. The first view assumes that all microorganisms are ubiquitous because their huge populations, small cells sizes (i.e., < $1 \mathrm{~mm}$ ), and capacities to produce resistant forms allow for a globally dispersal (Finlay and Clarke 1999). The second view assumes that at least some of them have limited geographical distributions (Foissner 1997; Foissner 1999; Foissner 2008; Vyverman et al. 2007). Although there is compelling evidence for biogeographical patterns in different groups of protists (Boo et al. 2010; Foissner 2006; Heger et al. 2011), the geographical distribution of most taxa remains unknown. Also, the processes that govern their diversity and biogeography remain poorly documented (Fontaneto 2011; Hanson et al. 2012; Heger et al. 2013). At local scales, protists are also under-sampled, although protistan species often exhibit very patchy distributions, especially

This article is protected by copyright. All rights reserved. 
in soils and marine sediments where spatial heterogeneity is common (Engel et al. 2012; Fenchel 1994; Rima and Aaron 2007; Weisse 2008). In addition to spatial variability, temporal variations can also be pronounced and can differ greatly among ecosystems and taxon groups (Behnke et al. 2010; Fenchel and Finlay 1986; Nolte et al. 2010). However, temporal variations of protists are relatively poorly documented, particularly in soil ecosystems (Fig. 2E) (Mitchell et al. 2011). Large-scale sampling campaigns such as the one recently organized by TARA (http://oceans.taraexpeditions.org) (Karsenti et al. 2011) or BIOMARKS (http://www.biomarks.eu) are needed to increase our knowledge about the overall diversity of protists, their spatial distributions and their temporal dynamics.

\section{Free-living heterotrophic protists}

Most protists have yet to be discovered, especially free-living heterotrophic species that occur in low abundance and have patchy distributions (Foissner 1999; Lèfevre et al. 2008; Lin et al. 2012; Orsi et al. 2011; Takishita et al. 2007). The discovery, characterization, and identification of freeliving heterotrophic protists that might play a crucial role in ecosystems are also complicated by the inherent difficulties of cultivating them, their small cell sizes, and the lack of conspicuous morphological traits (Boenigk et al. 2005; Boenigk 2008; Chantangsi and Leander 2010; Jost et al. 2010). Culture-independent assessments of diversity based on environmental PCR surveys or fluorescent in situ hybridization (FISH) have contributed greatly to our overall understanding of heterotrophic uncultured protistan biodiversity in aquatic and terrestrial environments (LópezGarcía et al. 2001; Stoeck et al. 2009). However, analyzing these data from field surveys is almost entirely dependent upon reference taxa that have already been characterized at the cellular, ecological, and behavioral levels. In spite of the difficulties associated with the identification and cultivation of heterotrophic flagellates, single-cell isolates from natural environments and the establishment of stable cultures remains a fundamentally important starting point for understanding the diversity and biology of heterotrophic protists.

New culture strains facilitate further investigations in diverse disciplines such as evolutionary biology, ecology, and cell and molecular biology. For instance, the discovery, cultivation and description of novel or poorly characterized protists, such as apusomonads, Breviata, Collodictyon, Mantamonas, Palpitomonas, Stephanopogon, Tsukubamonas, and fornicate excavates have contributed significantly to an improved understanding of ultrastructural evolution, eukaryote-prokaryote symbiotic relationships, organelle evolution, and the phylogenetic relationships of major lineages of eukaryotes (Brugerolle et al. 2002; Glücksman et al. 2011; Kolisko et al. 2010; Walker et al. 2006; Yabuki et al. 2010; 2011; Yubuki and Leander 2008; Yubuki et al. 2009). Reconstructing the molecular phylogenetic position and ultrastructural features of so-called "sister-less" or "orphan" lineages of heterotrophic protists (e.g., apusomonads, Breviata and Collodictyon) has facilitated inferences about the deepest ancestral states within the overall tree of eukaryotes (Kim et al. 2006, Roger and Simpson 2009, Yubuki and Leander 2013, Zhao et al. 2012). The biodiversity and taxonomic characterization of heterotrophic protists is also a key requirement for understanding their role in various environments (Glücksman et al. 2010; Guillou et al. 1999; Matz et al. 2002; Seenivasan et al. 2013).

This article is protected by copyright. All rights reserved. 


\section{Protists living with other organisms}

Many protists form symbioses with other protists, bacteria, animals, plants, or fungi, and such associations have important roles in ecosystem functioning and evolutionary diversification of those organisms involved (Graham et al. 2002; Paracer and Ahmadjian 2000). More comprehensive reviews on protist symbioses have been published elsewhere (e.g. Anderson 2012; Gast et al. 2009; Johnson 2011a; Johnson 2011b; Nowack and Melkonian 2010; Stoecker et al. 2009). Among the ecosystems surveyed for protist diversity, oligotrophic waters, in particular, appear to harbor many microbial consortia based on the limiting nutrient factors (Nowack and Melkonian 2010). For instance, in nutrient-poor surface ocean waters, diatoms such as Hemiaulus and Rhizosolenia associate with nitrogen-fixing cyanobacterial endosymbionts, which contribute significantly to the nitrogen budget of the diatom host (Carpenter et al. 1999; Foster et al. 2007). In oligotrophic Sphagnum-dominated peat bogs, nonphotosynthetic protists such as the ciliates Colpoda and Prorodon carry green algal endosymbionts, which provide fixed carbon to the heterotrophic host (Glime 2012). Associations between the radiolarian Acantharia and the haptophyte Phaeocystis are thought to originate in oligotrophic surface oceanic waters, where the pigmented algal endosymbiont presumably benefits the acantharian host by providing antioxidant protection (Decelle et al. 2012). In addition, a variety of protist-bacterial associations have been observed in low-oxygen environments (Bernhard et al. 2000). Some low-oxygen dwelling protists like the euglenozoans Calkinsia aureus, Bihospites bacati, and Postgaardi mariagerensis are covered with numerous bacterial epibionts, which appear to reduce sulfide toxicity in the host by consuming sulfur or sulfide compounds, and/or remove hydrogen produced by host hydrogenosomes, (Breglia et al. 2010; Edgcomb et al. 2011a). In anaerobic ciliates such as Plagiopyla frontata, intracellular methanogens occur in close contact with the hydrogenosomes of the ciliate for hydrogen-based syntrophy (Fenchel and Finlay 1995). In termite guts, anaerobic oxymonads and parabasalids possess many epibionts on their surface and/or intracellular bacteria. Symbioses involving protists occur in many other ecosystems, including eutrophic oceanic surface waters (Gomez 2007), estuaries (Stoecker et al. 1991), sandy beaches (Okamoto and Inouye 2006), and acid mine drainage (Baker et al. 2003), although the ecophysiological factors that facilitate much of these associations are unclear.

While a growing number of protist symbioses are being discovered each year (Nowack and Melkonian 2010), the majority of them still remain unknown to science. This may be partially explained by the difficulties and challenges associated with isolating and culturing symbiotic microbes under standard culturing conditions. For example, the marine katablepharid protist Hatena arenicola harboring the green alga Nephroselmis sp. (Okamoto and Inouye 2006) and the freshwater euglenid Petalomonas sphagnophila associating with several different kinds of endosymbiotic bacteria (Kim et al. 2010), have not been cultured despite numerous efforts. Furthermore, the symbiotic relationships could be altered during the culturing procedures, such as elimination of one or more partners in the case of facultative associations (e.g. Broers et al. 1993). For these reasons, the use of fresh field samples is often necessary for the study of protists that form symbioses with other organisms. While such sampling requirement has been a major impediment to the identification and characterization of protist symbioses, especially those in remote locations, technological advancements, such as on-board single cell cytometry (e.g. Thompson et al. 2012), new preservation tools, and single-cell genomics are opening up

This article is protected by copyright. All rights reserved. 
unprecedented opportunities to investigate a wider range of protist associations in diverse ecosystems.

\section{Parasitic protists}

Until relatively recently, few parasitic protists other than those affecting humans and/or economically important animals have been examined in detail. Typically, for the studies of pathogenicity, life cycle, ultrastructure, as well as its molecular and cell biology, the parasite usually had to be isolated and introduced into culture or obtained from a collection, such as American Type Culture Collection (ATCC). However, at present, one can study various aspects of molecular biology of parasitic protists using just tiny amounts of DNA and/or RNA that can be easily isolated, stored and shared between laboratories. Moreover, molecular methods now allow multiple and/or large-scale, rapid and efficient screening of DNA samples, which is particularly important for our understanding of the diversity and evolution of (parasitic) protists (Kolisko et al. 2008). Recent analyses of environmental sequence data identified novel free-living sister clades of the obligatory parasitic groups, prominent examples being marine stramenopile cluster 12 (MAST 12) as a close relative of the human parasite, Blastocystis (Massana et al. 2006). Culture dependent molecular analyses also revealed chromerids and the Carpediemonas-like organisms as relatives of apicomplexans and diplomonads, respectively (Kolisko et al. 2010; Moore et al. 2008) and, even more importantly, indicate that protists may constitute up to $3 / 4$ of all extant eukaryotic diversity (Pawlowski et al. 2012). In general, most parasitic protists do not possess a wealth of distinguishing morphological features, yet molecular techniques provide the discriminatory power to map their unexpectedly wide genetic diversity. The genomes of parasitic protists, accessible in the era of whole-genome sequencing and single-cell genomics (Kalisky and Quake 2011), hold promise to provide critical insight into the adaptations for parasitism, particularly successful in the above-mentioned widespread protists.

The power of molecular techniques combined with field collections can be demonstrated on two groups of historically well-studied parasites - trypanosomes and plasmodia. Trypanosomes, leishmanias and related flagellates are known for their dearth of morphological features. A few years ago, it was proposed that the species abundance of insect hosts in combination with postulated high host specificity of insect-dwelling trypanosomatids means the number of species of these protists must reach millions (Stevens 2001). At that time only a handful of species isolated from insects was available in culture (Maslov et al. 1994) and such an exciting theory seemed to be hardly testable in the foreseeable future. However, despite being relatively limited in scope, a renewed emphasis on field collections (Fig. 2F) already provided major insight into the varied biodiversity landscape of these important parasites (Maslov et al. 2013). While in some trypanosomatid clades a strict host specificity indeed holds, in several instances the same flagellate species was encountered in different heteropteran hosts coming from different continents, strongly indicating that the global diversity of these protists is lower than what was predicted based on the "one host- one parasite" paradigm (Votýpka et al. 2012). At the same time, molecular techniques revealed far greater than anticipated genetic diversity of Trypanosoma spp. in the thoroughly and long studied tse-tse flies (Adams et al. 2010) and recently identified a novel monospecific clade that represents a sister group to all trypanosomatids (Flegontov et al. 2013).

This article is protected by copyright. All rights reserved. 
The finding that Plasmodium DNA can be PCR-amplified from field-collected fecal samples opened an avenue to investigate its diversity in big apes and monkeys (Liu et al. 2010), and in fact in other endangered animals, for which tissue samples are virtually inaccessible. Extensive analyses of feces collected in the environment inhabited by big apes led to the proposal that the human pernicious Plasmodium falciparum, responsible for the death of over a million people annually, may have been originally acquired from gorillas (Rayner et al. 2011) or other primates (Prugnolle et al. 2011). In any case, the power of PCR and single-cell genomics allow studies of parasitic protists that were until recently, for one reason or another, beyond reach.

\section{Why are data from protistan field studies limited?}

There are several methodological and conceptual challenges that help explain why protistan field data remains limited. First of all, despite the invention of light microscopy more than three centuries ago, the application of electron microscopy to biological materials in the mid 1900's, and recent developments in molecular approaches, protists remain difficult to discover and identify because of their small body size, their patchy distributions, the low abundance of many species, and difficulties associated with cultivation. Furthermore, challenges associated with sampling, the comparatively small number of active "field protistologists", and limited public interest in these organisms contribute directly and indirectly to the lack of data in several protistological disciplines.

\section{Sampling challenges: case study in the deep sea}

There are many approaches to field sampling for isolation of protists in enrichment or pure cultures, or for the purpose of isolating nucleic acids or other biomolecules. Sampling surface waters (Fig. 2A), soils and nearshore or shallow sediments can be accomplished in a myriad of ways. All sampling and isolation methods have the potential to introduce biases to some usually unknown extent. These biases range from the difficulties associated with adequate cell preservation of different protist taxa for microscopy, or replicating in situ conditions enough to encourage the growth of many protists (particularly in isolation) with currently known culturing approaches, to biases in recovery of the protists or their biomolecules from the original sample material prior to initiating experiments.

Deep ocean realms remain largely understudied regarding protist diversity. Studies of mesopelagic and bathypelagic marine water columns and sediments to date have revealed signatures and images of diverse protist communities that include many taxonomic groups without close cultured relatives (e.g., Edgcomb et al. 2011a; 2011b; Epstein and Lopez-Garcia 2008; Lopez-Garcia et al. 2001; Orsi et al. 2011). When it comes to sampling the deep ocean, these concerns are particularly great, because protists are also exposed to significant changes in pressure that can potentially impact cell metabolic state and integrity (Edgcomb et al. 2011c). Current studies of pelagic marine microbial communities rely heavily on ship-based hydrocasting operations (Fig. 2B) whereby water samples from various depths in the ocean are brought to the surface via Niskin rosette samplers (Figs. 2C-D). Samples are then typically

This article is protected by copyright. All rights reserved. 
drawn from the Niskin bottle for subsequent culture-based, phylogenetic, and/or functional molecular analyses. Niskin sampling will always have a role in oceanography and some aspects of marine microbial ecology, but it is more limiting for rate process measurements and gene expression studies where the very act of bringing the samples from the environment to the ship's deck can result in dramatic modification of physiological states. This can manifest in (often undetected) community structure alterations, particularly for anoxic and/or deep-water column environments.

Research trends in marine microbial ecology are transitioning from purely descriptive studies of diversity to integrated studies of in situ activity and microbial responses to changing environmental conditions. Therefore, systems-level investigations of microbial community responses to changing levels of water column oxygen deficiency, including studies of protozoa, are essential to our understanding of ecological phenomena intrinsic to ocean productivity and climate balance. Given the typically short half-life of mRNA (e.g. minutes) (Andersson et al. 2006; Selinger et al. 2003; Wang et al. 2002) it is especially difficult to conduct meaningful studies of gene expression, when upwards of 30-45 minutes can pass between enclosure of the sample in a Niskin bottle at depth and filtration/fixation in the ship's laboratory. By the time the water samples reach the deck of the ship and are processed, sample conditions (pressure, temperature, light, redox state [sample contamination by $\mathrm{O}_{2}$ dissolved in \& diffused from the plastic Niskin bottle walls]) are often significantly altered from the environment from which the samples came. While DNA (not an indicator of cell viability but selected genes commonly used as phylogenetic identifiers) and rRNA are less susceptible to such biases due to their significantly longer half-lives, delayed preservation of such samples can still be an issue if cell integrity is lost due to unnatural and changing conditions during transport from the ocean environment to the ship's laboratory. Variable and unknown fractions of genetic material from lysed cells can be lost during filtration. This problem is particularly severe for the more fragile marine protists and potentially compounded when sampling greater depths.

Many microbial eukaryotes are extremely sensitive to physico-chemical changes, particularly oxidation-reduction (redox) state, pressure, and temperature; consequently Niskin sampling only recovers a fraction of the total in situ community from anoxic waters and redox interfaces below $250 \mathrm{~m}$. Microscope observations of fixed Niskin samples from the oxic/anoxic interface and from two depths deeper within the anoxic zone $(340 \mathrm{~m}$ and $900 \mathrm{~m})$ in the Cariaco Basin, Venezuela, where molecular signatures indicated a diverse community (Orsi et al. 2011), showed few signs of living eukaryotes. When samples from deeper anoxic waters were preserved in situ using a pre-programmed remote water sampler, they revealed a minimum two orders of magnitude greater protist cell count (unpublished data) and provided scanning electron microscopy images of the first novel class of ciliates to be documented on the basis of both molecular and microscopic data in over a decade (Orsi et al. 2012). As new technologies for in situ water column sampling and preservation for microbiological studies are developed, we will be better positioned to examine protist populations and their activities in the deep sea.

This article is protected by copyright. All rights reserved. 


\section{Future perspectives and conclusions}

It is a very exciting time for researchers interested in protists. Constant efforts for cultivating new and poorly studied organisms from field surveys and the use of efficient and inexpensive molecular approaches combined with high-end microscopical methods, together represent an unprecedented opportunity to provide enormous insights into fundamental questions in biology. These new data are contributing to (1) the discovery of new lineages that expand the tree of eukaryotes; (2) the recognition of novel evolutionary patterns and processes; (3) the untangling of ecological interactions and functions, and their roles in larger ecosystem processes; (4) the evaluation of protists' ability to adapt to changing climates, and (5) the development of new biomonitoring approaches. However, in order to address these objectives, several obstacles still need to be overcome. Firstly, Next-Generation sequencing techniques, which are widely used, must be improved to produce longer read sequences of higher quality that will allow for better taxonomic assignments. Furthermore, these approaches need to be paired with microscopical examinations of samples to improve the analysis and interpretation of molecular data. Secondly, it is crucial to increase the sampling of protists through large-scale sampling campaigns across different geographical regions, ecosystems and time-scales. These efforts will not only lead to informative culture-based and other studies, but resulting genetic data deposited in public databases will improve taxonomic assignments of sequences recovered in Next-Generation datasets. Thirdly, material and data obtained directly or indirectly from the field (e.g., DNA extraction, sequences, light and scanning microscopy pictures, fresh and cryopreserved cultures) should be more systematically deposited in public collections to improve access to a wider collection by the broader community. Fourthly, at a time when funding agencies are routinely showing preference for hypothesis-driven research, it is important to emphasize and promote that exploratory research is essential to different disciplines in protistology, and to any sound understanding of biodiversity. Finally, this advocacy will help to ensure that funding agencies support ambitious research projects in protistology and facilitate collaborative interdisciplinary projects which, for instance, will integrate protists in long-term and multi-trophic experiments.

\section{ACKNOWLEDGMENTS}

This review is the direct result of the symposium "Field protistology: cornerstone for understanding the diversity, ecology and evolution of microbial eukaryotes" held during the Protist 2012 meeting, Oslo, Norway. We thank the International Society of Protistologists as well as the Tula Foundation's Centre for Microbial Diversity and Evolution at the University of British Columbia for funding this symposium. B.S.L. and J.L. are fellows of the Canadian Institute for Advanced Research. T.H is supported by the Swiss Science Fundation (project PA00P3 145374). Finally, we thank three anonymous referees and one associate editor for providing numerous comments on this manuscript.

\section{LITERATURE CITED}

Adams, E. R., Hamilton, P. B. \& Gibson, W. C. 2010. African trypanosomes: celebrating diversity. Trends Parasitol., 26:324-328.

This article is protected by copyright. All rights reserved. 
Adl, S. M., Leander, B. S., Simpson, A. G. B., Archibald, J. M., Anderson, O. R., Bass, D., Bowser, S. S., Brugerolle, G., Farmer, M. A., Karpov, S., Kolisko, M., Lane, C. E., Lodge, D. J., Mann, D. G., Meisterfeld, R., Mendoza, L., Moestrup, O., MozleyStandridge, S. E., Smirnov, A. V. \& Spiegel, F. 2007. Diversity, nomenclature, and taxonomy of protists. Syst. Biol., 56:684-689.

Anderson, O. R. 2012. Living together in the plankton: a survey of marine protist symbioses. Acta Protozool., 52:1-10.

Andersson, A. F., Lundgren, M., Eriksson, S., Rosenlund, M., Bernander, R. \& Nilsson, P. 2006. Global analysis of mRNA stability in the archaeon Sulfolobus. Genome Biol., 7.

Baker, B. J., Hugenholtz, P., Dawson, S. C. \& Banfield, J. F. 2003. Extremely acidophilic protists from acid mine drainage host Rickettsiales-lineage endosymbionts that have intervening sequences in their 16S rRNA genes. Appl. Environ. Microbiol., 69:5512-5518.

Behnke, A., Barger, K. J., Bunge, J. \& Stoeck, T. 2010. Spatio-temporal variations in protistan communities along an $\mathrm{O}_{2} / \mathrm{H}_{2} \mathrm{~S}$ gradient in the anoxic Framvaren Fjord (Norway). FEMS Microbiol. Ecol., 72:89-102.

Bernhard, J. M., Buck, K. R., Farmer, M. A. \& Bowser, S. S. 2000. The Santa Barbara Basin is a symbiosis oasis. Nature, 403:77-80.

Boenigk, J. 2008. The past and present classification problem with nanoflagellates exemplified by the genus Monas. Protist, 159:319-337.

Boenigk, J., Pfandl, K., Stadler, P. \& Chatzinotas, A. 2005. High diversity of the 'Spumella-like' flagellates: an investigation based on the SSU rRNA gene sequences of isolates from habitats located in six different geographic regions. Environ. Microbiol., 7:685-697.

Boenigk, J., Ereshefsky, M., Hoef-Emden, K., Mallet, J. \& Bass, D. 2012. Concepts in protistology: Species definitions and boundaries. Eur. J. Protistol., 48:96-102.

Boo, S. M., Kim, H. S., Shin, W., Boo, G. H., Cho, S. M., Jo, B. Y., Kim, J. H., Yang, E. C., Siver, P. A., Wolfe, A. P., Bhattacharya, D., Andersen, R. A. \& Yoon, H. S. 2010. Complex phylogeographic patterns in the freshwater alga Synura provide new insights into ubiquity vs. endemism in microbial eukaryotes. Mol. Ecol., 19:4328-4338.

Brady, H. B. 1876. A monograph of Carboniferous and Permian Foraminifera London. p. 166.

Breglia, S. A., Yubuki, N., Hoppenrath, M. \& Leander, B. S. 2010. Ultrastructure and molecular phylogenetic position of a novel euglenozoan with extrusive episymbiotic bacteria: Bihospites bacati n. gen. et sp. (Symbiontida). BMC Microbiol., 10.

Broers, C. A., Meijers, H. H., Symens, J. C., Stumm, C. K., Vogels, G. D., Brugerolle, G. 1993. Symbiotic association of Psalteriomons vulgaris n. spec. with Methanobacterium formicicum. Eur. J. Protistol., 29 :98-105.

Brugerolle, G., Bricheux, G., Philippe, H. \& Coffe, G. 2002. Collodictyon triciliatum and Diphylleia rotans (=Aulacomonas submarina) form a new family of flagellates (Collodictyonidae) with tubular mitochondrial cristae that is phylogenetically distant from other flagellate groups. Protist, 153:59-70.

Butler, H. \& Rogerson, A. 1995. Temporal and spatial abundance of naked amebas (Gymnamoebae) in marine benthic sediments of the Clade-Sea area, Scotland. J.Euk. Microbiol., 42:724-730.

Carpenter, E. J., Montoya, J. P., Burns, J., Mulholland, M. R., Subramaniam, A. \& Capone, D. G. 1999. Extensive bloom of a $\mathrm{N}_{-2}$-fixing diatom/cyanobacterial association in the tropical Atlantic Ocean. Mar. Ecol. Prog. Ser., 185:273-283.

This article is protected by copyright. All rights reserved. 
Chantangsi, C. \& Leander, B. S. 2010. An SSU rDNA barcoding approach to the diversity of marine interstitial cercozoans, including descriptions of four novel genera and nine novel species. Int. J. Syst. Evol. Microbiol., 60:1962-1977.

Decelle, J., Probert, I., Bittner, L., Desdevises, Y., Colin, S., de Vargas, C., Gali, M., Simo, R. \& Not, F. 2012. An original mode of symbiosis in open ocean plankton. P Natl Acad. Sci. USA, 109:18000-18005.

Dobell, C. 1923. A protozoological bicentenary: Antony van Leeuwenhoek (1632-1723) and Louis Joblot (1645-1723). Parasitol., 15:308-319.

Edgcomb, V., Orsi, W., Bunge, J., Jeon, S., Christen, R., Leslin, C., Holder, M., Taylor, G. T., Suarez, P., Varela, R. \& Epstein, S. 2011a. Protistan microbial observatory in the Cariaco Basin, Caribbean. I. Pyrosequencing vs Sanger insights into species richness. ISME J., 5:1344-1356.

Edgcomb, V.P., Orsi, W., Breiner, H.-W. Stock, A. Filker, S. Yakimov, M.M. \& Stoeck, T. 2011 b. Novel kinetoplastids associated with hypersaline anoxic lakes in the Eastern Mediterranean deep-sea. Deep-Sea Research I, 58:1040-1048.

Edgcomb, V.P., Orsi, W., Taylor, G.T., Vdacny, P., Taylor, C., Suarez, P., \& Epstein, S. 2011c. Accessing marine protists from the anoxic Cariaco Basin. ISME J., 5:1237-1241.

Engel, M., Behnke, A., Bauerfeld, S., Bauer, C., Buschbaum, C., Volkenborn, N. \& Stoeck, T. 2012. Sample pooling obscures diversity patterns in intertidal ciliate community composition and structure. FEMS Microbiol. Ecol., 79:741-750.

Epstein, S. \& Lopez-Garcia, P. 2008. "Missing" protists: a molecular perspective. Biodivers Conserv., 17:261-276.

Fenchel, T. 1994. Microbial ecology on land and sea. Phil. Trans. R. Soc. B.,, 343:51-56.

Fenchel, T. \& Finlay, B. J. 1986. Photobehavior of the ciliated protooan Loxodes - Taxic, transient, and kinetic responses in the presence and absence of oxygen. J.Protozool., 33:139-145.

Fenchel, T. \& Finlay, B. J. 1995. Ecology and Evolution in Anoxic Worlds. Oxford University Press, Oxford

Finlay, B. J. \& Clarke, K. J. 1999. Ubiquitous dispersal of microbial species. Nature, 400:828828.

Flegontov, P., Votýpka, J., Skalický, T., Logacheva, M.D., Penin, A.A., Tanifuji, G., Onodera, N.T., Kondrashov, A.S., Volf, P., Archibald, J.M. \& Lukeš, J. 2013. Paratrypanosoma is a novel early-branching trypanosomatid. Curr. Biol., 23: 1787-1793.

Foissner, W. 1999. Protist diversity: Estimates of the near-imponderable. Protist, 150:363-368.

Foissner, W. 1997. Global soil ciliate (Protozoa, ciliophora) diversity: a probability-based approach using large sample collections from Africa, Australia and Antarctica. Biodiverss Conserv., 6:1627-1638.

Foissner, W. 2006. Biogeography and dispersal of micro-organisms: A review emphasizing protists. Acta Protozool., 45:111-136.

Foissner, W. 2008. Protist diversity and distribution: some basic considerations. Biodiverss Conserv., 17:235-242.

Fontaneto, D. 2011. Biogeography of microscopic organisms. Cambridge University Press, Cambridge. p. 365.

Foster, R. A., Subramaniam, A., Mahaffey, C., Carpenter, E. J., Capone, D. G. \& Zehr, J. P. 2007. Influence of the Amazon River plume on distributions of free-living and symbiotic

This article is protected by copyright. All rights reserved. 
cyanobacteria in the western tropical north Atlantic Ocean. Limnol. Oceanogr., 52:517532.

Frias-Lopez, J., Shi, Y., Tyson, G. W., Coleman, M. L., Schuster, S. C., Chisholm, S. W. \& DeLong, E. F. 2008. Microbial community gene expression in ocean surface waters. Proc. Natl. Acad. Sci. U.S.A., 105:3805-3810.

Gast, R. J., Sanders, R. W. \& Caron, D. A. 2009. Ecological strategies of protists and their symbiotic relationships with prokaryotic microbes. Trends Microbiol., 17:563-569.

Glime, J. M. 2012. Protozoa Diversity. In: Bryologists, M. T. U. a. t. I. A. o. (ed.) Bryophyte Ecology. 2.

Glücksman, E., Bell, T., Griffiths, R. I. \& Bass, D. 2010. Closely related protist strains have different grazing impacts on natural bacterial communities. Environ. Microbiol., 12:31053113.

Glücksman, E., Snell, E. A., Berney, C., Chao, E. E., Bass, D. \& Cavalier-Smith, T. 2011. The novel marine gliding zooflagellate genus Mantamonas (Mantamonadida ord. n.: Apusozoa). Protist, 162:207-221.

Gomez, F. 2007. The consortium of the protozoan Solenicola setigera and the diatom Leptocylindrus mediterraneus in the Pacific Ocean. Acta Protozool., 46:15-24.

Graham, L. E., Graham, J. M. \& Wilcox, L. W. 2002. Algae. Benjamin Cummings, San Francisco, CA

Guillou, L., Moon-Van Der Staay, S. Y., Claustre, H., Partensky, F. \& Vaulot, D. 1999. Diversity and abundance of bolidophyceae (Heterokonta) in two oceanic regions. Appl. Environ. Microb., 65:4528-4536.

Guillou, L., Bachar, D., Audic, S., Bass, D., Berney, C., Bittner, L., Boutte, C., Burgaud, G., de Vargas, C., Decelle, J., del Campo, J., Dolan, J. R., Dunthorn, M., Edvardsen, B., Holzmann, M., Kooistra, W. H. C. F., Lara, E., Le Bescot, N., Logares, R., Mahé, F., Massana, R., Montresor, M., Morard, R., Not, F., Pawlowski, J., Probert, I., Sauvadet, A.L., Siano, R., Stoeck, T., Vaulot, D., Zimmermann, P. \& Christen, R. 2013. The Protist Ribosomal Reference database (PR2): a catalog of unicellular eukaryote Small Sub-Unit rRNA sequences with curated taxonomy. Nucleic Acids Res., 41:597-604.

Guiry, M. D. \& Guiry, G. M. 2013. AlgaeBase. World-wide electronic publication, National University of Ireland, Galway. http://www.algaebase.org:searched on 21 February 2013.

Hanson, C. A., Fuhrman, J. A., Horner-Devine, M. C. \& Martiny, J. B. H. 2012. Beyond biogeographic patterns: processes shaping the microbial landscape. Nat. Rev. Microbiol., 10:497-506.

Heger, T. J., Mitchell, E. A. D. \& Leander, B. S. 2013. Holarctic phylogeography of the testate amoeba Hyalosphenia papilio (Amoebozoa: Arcellinida) reveals extensive genetic diversity explained more by environment than dispersal limitation. Mol. Ecol., 22: 51725184.

Heger, T. J., Booth, R. K., Sullivan, M. E., Warner, B. G., Asada, T., Wilkinson, D. W., Mazei, Y., Meisterfeld, R. \& Mitchell, E. A. D. 2011. Rediscovery of Nebela ansata (Protista: Arcellinida) in the eastern North-America- Biogeographical implications. J. Biogeogr., 38:1897-1906.

Jablot, L. 1718. Descriptions et usages de plusieurs nouveaux microscopes, tant simples que composez: avec de nouvelles observations faites sur une multitude innombrable d'insectes, et d'autres animaux de diverses espèces, qui naissent dans les liqueurs préparées et dans celles qui ne le sont point. Paris, Jacques Collombat.

This article is protected by copyright. All rights reserved. 
Johnson, M. D. 2011a. Acquired Phototrophy in Ciliates: A Review of Cellular Interactions and Structural Adaptations. J. Eukaryot. Microbiol., 58:185-195.

Johnson, M. D. 2011b. The acquisition of phototrophy: adaptive strategies of hosting endosymbionts and organelles. Photosynth. Res., 107:117-132.

Jost, S., Medinger, R. \& Boenigk, J. 2010. Cultivation-independent species identification of Dinobryon species (Chrysophyceae) by means of multiplex single-cell PCR. J. Phycol., 46:901-906.

Kalisky, T. \& Quake, S. R. 2011. Single-cell genomics. Nature Methods 8:311-341.

Karsenti, E., Acinas, S.G., Bork, P., Bowler, C., de Vargas, C., Raes, J., Sullivan, M., Arendt, D., Benzoni, F., Claverie, J.-M., Follows, M., Gorsky, G., Hingamp, P., Iudicone, D., Jaillon, O., Kandels-Lewis, S., Krzic, U., Not, F., Ogata, H., Pesant, S., Reynaud, E.G., Sardet, C., Sieracki, M.E., Speich, S., Velayoudon, D., Weissenbach, J. \& Wincker, P. 2011. A holistic approach to marine Eco-systems biology. PLoS Biol. 9, e1001177.

Kim, E., Simpson, A. G. B. \& Graham, L. E. 2006. Evolutionary relationships of apusomonads inferred from taxon-rich analyses of 6 nuclear encoded genes. Mol. Biol. Evol., 23:24552466.

Kim, E., Park, J. S., Simpson, A. G. B., Matsunaga, S., Watanabe, M., Murakami, A., Sommerfeld, K., Onodera, N. T. \& Archibald, J. M. 2010. Complex array of endobionts in Petalomonas sphagnophila, a large heterotrophic euglenid protist from Sphagnumdominated peatlands. ISME J., 4:1108-1120.

Knapp, A. K., Smith, M. D., Hobbie, S. E., Collins, S. L., Fahey, T. J., Hansen, G. J. A., Landis, D. A., La Pierre, K. J., Melillo, J. M., Seastedt, T. R., Shaver, G. R. \& Webster, J. R. 2012. Past, present, and future roles of long-term experiments in the LTER network. Bioscience, 62:377-389.

Kolisko, M., Čepička, I., Hampl, V., Leigh, J., Roger, A. J., Kulda, J., Simpson, A.G.B. \& Flegr, J. 2008. Molecular phylogeny of diplomonads and enteromonads based on SSU rRNA, atubulin and HSP90 genes: implications for the evolutionary history of the double karyomastigont of diplomonads. BMC Evol. Biol., 8: 205

Kolisko, M., Silberman, J. D., Čepička, I., Yubuki, N., Takishita, K., Yabuki, A., Leander, B. S., Inouye, I., Inagaki, Y., Roger, A. J. \& Simpson, A. G. B. 2010. A wide diversity of previously undetected free-living relatives of diplomonads isolated from marine/saline habitats. Environ. Microbiol., 12:2700-2710.

Lechevalier, H. 1976. Louis Joblot and his microscopes Bacteriol. Rev., 40:241-258.

Lefèvre, E., Roussel, B., Amblard, C. \& Sime-Ngando, T. 2008. The molecular diversity of freshwater picoeukaryotes reveals high occurrence of putative parasitoids in the plankton. PLoS One, 3.

Lin, Y. C., Campbell, T., Chung, C. C., Gong, G. C., Chiang, K. P. \& Worden, A. Z. 2012. Distribution patterns and phylogeny of marine stramenopiles in the North Pacific Ocean. Appl. Environ. Microb., 78:3387-3399.

Liu, W. M., Li, Y. Y., Learn, G. H., Rudicell, R. S., Robertson, J. D., Keele, B. F., Ndjango, J. B. N., Sanz, C. M., Morgan, D. B., Locatelli, S., Gonder, M. K., Kranzusch, P. J., Walsh, P. D., Delaporte, E., Mpoudi-Ngole, E., Georgiev, A. V., Muller, M. N., Shaw, G. M., Peeters, M., Sharp, P. M., Rayner, J. C. \& Hahn, B. H. 2010. Origin of the human malaria parasite Plasmodium falciparum in gorillas. Nature, 467:420-U67.

López-García, P., Rodriguez-Valera, F., Pedros-Alio, C. \& Moreira, D. 2001. Unexpected diversity of small eukaryotes in deep-sea Antarctic plankton. Nature, 409:603-607.

This article is protected by copyright. All rights reserved. 
Mann, D. G. \& Droop, S. J. M. 1996. Biodiversity, biogeography and conservation of diatoms. Hydrobiologia, 336:19-32.

Maslov, D. A., Avila, H. A., Lake, J. A. \& Simpson, L. 1994. Evolution of RNA editing in kinetoplastid protozoa. Nature, 368:345-348.

Maslov, D. A., Votýpka, J., Yurchenko, V. \& Lukeš, J. 2013. Diversity and phylogeny of insect trypanosomatids: all that is hidden shall be revealed. Trends Parasitol., 29:43-52.

Massana, R., Terrado, R., Forn, I., Lovejoy, C. \& Pedros-Alio, C. 2006. Distribution and abundance of uncultured heterotrophic flagellates in the world oceans. Env. Microb., $8: 1515-1522$.

Matz, C., Boenigk, J., Arndt, H. \& Jurgens, K. 2002. Role of bacterial phenotypic traits in selective feeding of the heterotrophic nanoflagellate Spumella sp. Aquat. Microb. Ecol., 27:137-148.

Mitchell, E. A. D., Belbahri, L., Job, D., Pawlowski, J. \& Lara, E. 2011. Exploring the Terra incognita of unknown eukaryotic diversity in soils - a major challenge we now have the tools to tackle! Bulletin BGS, 32:57-62.

Moore, R. B., Oborník, M., Janouškovec, J., Chrudimský, T., Vancová, M., Green, D. H., Wright, S. W., Davies, N. W., Bolch, C. J. S., Heimann, K., Slapeta, J., Hoegh-Guldberg, O., Logsdon, J. M. \& Carter, D. A. 2008. A photosynthetic alveolate closely related to apicomplexan parasites. Nature, 451:959-963.

Müller, O. F. 1786. Animalcula infusoria fluviatilia et marina quæ detexit, systematice descripsit et ad vivum delineari curavit. Copenhagen. p. 367.

Nolte, V., Pandey, R. V., Jost, S., Medinger, R., Ottenwalder, B., Boenigk, J. \& Schlotterer, C. 2010. Contrasting seasonal niche separation between rare and abundant taxa conceals the extent of protist diversity. Mol. Ecol., 19:2908-2915.

Norton, T. A., Melkonian, M. \& Andersen, R. A. 1996. Algal biodiversity. Phycologia, 35:308326.

Nowack, E. C. M. \& Melkonian, M. 2010. Endosymbiotic associations within protists. Phil. Trans. R. Soc. B, 365:699-712.

Okamoto, N. \& Inouye, I. 2006. Hatena arenicola gen. et sp nov., a katablepharid undergoing probable plastid acquisition. Protist, 157:401-419.

Orsi, W., Edgcomb, V., Jeon, S., Leslin, C., Bunge, J., Taylor, G. T., Varela, R. \& Epstein, S. 2011. Protistan microbial observatory in the Cariaco Basin, Caribbean. II. Habitat specialization. ISME J., 5:1357-1373.

Orsi, W., Edgcomb, V., Faria, J., Foissner, W., Fowle, W. H., Hohmann, T., Suarez, P., Taylor, C., Taylor, G. T., Vd'ačný, P. \& Epstein, S. S. 2012. Class Cariacotrichea, a novel ciliate taxon from the anoxic Cariaco Basin, Venezuela. Int. J. Syst. Evol. Microbiol., 62:14251433.

Paracer, S. \& Ahmadjian, V. 2000. Symbiosis: An Introduction to Biological Associations. Oxford University Press, Cary. p. 304.

Pawlowski, J., Audic, S., Adl, S., Bass, D., Belbahri, L., Berney, C., Bowser, S. S., Cepicka, J., Decelle, J., Dunthorn, M., Fiore-Donno, A. M., Gile, G. H., Holzmann, M., Jahn, R., Jirku, M., Keeling, P. J., Kostka, M., Kudryavtsev, A., Lara, E., Lukě̌, J., Mann, D. G., Mitchell, E. A. D., Nitsche, F., Romeralo, M., Saunders, G. W., Simpson, A. G. B., Smirnov, A. V., Spouge, J. L., Stern, R. F., Stoeck, T., Zimmermann, J., Schindel, D. \& de Vargas, C. 2012. CBOL protist working group: barcoding eukaryotic richness beyond the animal, plant, and fungal kingdoms. PLoS Biol., 10: e1001419.

This article is protected by copyright. All rights reserved. 
Prugnolle, F., Ollomo, B., Durand, P., Yalcindag, E., Arnathau, C., Elguero, E., Berry, A., Pourrut, X., Gonzalez, J. P., Nkoghe, D., Akiana, J., Verrier, D., Leroy, E., Ayala, F. J. \& Renaud, F. 2011. African monkeys are infected by Plasmodium falciparum nonhuman primate-specific strains. Proc. Natl. Acad. Sci. U.S.A., 108:11948-11953.

Rayner, J. C., Liu, W. M., Peeters, M., Sharp, P. M. \& Hahn, B. H. 2011. A plethora of Plasmodium species in wild apes: a source of human infection? Trends Parasitol., 27:222-229.

Rima, F. B. \& Aaron, M. L. 2007 Spatial Distribution of Microbes in the Environment. Springer Dordrecht.

Roger, A. J. \& Simpson, A. G. B. 2009. Evolution: revisiting the root of the eukaryote tree. Curr. Biol., 19:R165-R167.

Seenivasan, R., Sausen, N., Medlin, L. K. \& Melkonian, M. 2013. Picomonas judraskeda gen. et sp. nov.: The first identified member of the Picozoa phylum nov., a widespread group of picoeukaryotes, formerly known as 'Picobiliphytes'. PLoS One, 8.

Selinger, D. W., Saxena, R. M., Cheung, K. J., Church, G. M. \& Rosenow, C. 2003. Global RNA half-life analysis in Escherichia coli reveals positional patterns of transcript degradation. Genome Res., 13:216-223.

Stevens, J. R. 2001. One million insects - a lot of parasites? Trends Parasitol., 17:119.

Stoeck, T., Behnke, A., Christen, R., Amaral-Zettler, L., Rodriguez-Mora, M. J., Chistoserdov, A., Orsi, W. \& Edgcomb, V. P. 2009. Massively parallel tag sequencing reveals the complexity of anaerobic marine protistan communities. BMC Biology, 7.

Stoecker, D. K., Johnson, M. D., de Vargas, C. \& Not, F. 2009. Acquired phototrophy in aquatic protists. Aquat. Microb. Ecol., 57:279-310.

Stoecker, D. K., Putt, M., Davis, L. H. \& Michaels, A. E. 1991. Photosynthesis in Mesodinium rubrum: species-specific measurements and comparison to community rates. Mar. Ecol. Prog. Ser., 73:245-252.

Stramma, L., Johnson, G. C., Sprintall, J. \& Mohrholz, V. 2008. Expanding oxygen-minimum zones in the tropical oceans. Science, 320:655-658.

Takishita, K., Yubuki, N., Kakizoe, N., Inagaki, Y. \& Maruyama, T. 2007. Diversity of microbial eukaryotes in sediment at a deep-sea methane cold seep: surveys of ribosomal DNA libraries from raw sediment samples and two enrichment cultures. Extremophiles, 11:563576.

Thompson, A. W., Foster, R. A., Krupke, A., Carter, B. J., Musat, N., Vaulot, D., Kuypers, M. M., Zeher, J. P. 2012. Unicellular cyanobacterium symbiotic with a single-celled eukaryotic algal. Science, 337:1546-1550.

Votýpka, J., Klepetková, H., Jirků, M., Kment, P. \& Lukeš, J. 2012. Phylogenetic relationships of trypanosomatids parasitising true bugs (Insecta: Heteroptera) in sub-Saharan Africa. Int. J. Parasitol., 42:489-500.

Vyverman, W., Verleyen, E., Sabbe, K., Vanhoutte, K., Sterken, M., Hodgson, D. A., Mann, D. G., Juggins, S., De Vijver, B. V., Jones, V., Flower, R., Roberts, D., Chepurnov, V. A., Kilroy, C., Vanormelingen, P. \& De Wever, A. 2007. Historical processes constrain patterns in global diatom diversity. Ecology, 88:1924-1931.

Walker, G., Dacks, J. B. \& Embley, T. M. 2006. Ultrastructural description of Breviata anathema, n. gen., n. sp., the organism previously studied as "Mastigamoeba invertens". J. Eukaryot. Microbiol., 53:65-78.

This article is protected by copyright. All rights reserved. 
Walsh, D. A., Zaikova, E., Howes, C. G., Song, Y. C., Wright, J. J., Tringe, S. G., Tortell, P. D. \& Hallam, S. J. 2009. Metagenome of a versatile chemolithoautotroph from expanding oceanic dead zones. Science, 326:578-582.

Wang, Y. L., Liu, C. L., Storey, J. D., Tibshirani, R. J., Herschlag, D. \& Brown, P. O. 2002. Precision and functional specificity in mRNA decay. Proc. Natl. Acad. Sci. U.S.A., 99:5860-5865.

Weisse, T. 2008. Distribution and diversity of aquatic protists: an evolutionary and ecological perspective. Biodiver. Conserv., 17:243-259.

Whitney, F. A., Freeland, H. J. \& Robert, M. 2007. Persistently declining oxygen levels in the interior waters of the eastern subarctic Pacific. Prog. Oceanogr., 75:179-199.

Yabuki, A., Inagaki, Y. \& Ishida, K. 2010. Palpitomonas bilix gen. et sp. nov.: A novel deepbranching heterotroph possibly related to Archaeplastida or Hacrobia. Protist, 161:523538.

Yabuki, A., Nakayama, T., Yubuki, N., Hashimoto, T., Ishida, K. I. \& Inagaki, Y. 2011. Tsukubamonas globosa n. gen., n. sp., a novel excavate flagellate possibly holding a key for the early evolution in "Discoba". J. Eukaryot. Microbiol., 58:319-331.

Yubuki, N. \& Leander, B. S. 2013. Evolution of microtubule organizing centers across the tree of eukaryotes. The Plant J., 75:230-244.

Yubuki, N. \& Leander, B. S. 2008. Ultrastructure and molecular phylogeny of Stephanopogon minuta: An enigmatic microeukaryote from marine interstitial environments. Eur. J. Protistol., 44:241-253.

Yubuki, N., Edgcomb, V. P., Bernhard, J. M. \& Leander, B. S. 2009. Ultrastructure and molecular phylogeny of Calkinsia aureus: cellular identity of a novel clade of deep-sea euglenozoans with epibiotic bacteria. BMC Microbiology, 9.

Zaikova, E., Walsh, D. A., Stilwell, C. P., Mohn, W. W., Tortell, P. D. \& Hallam, S. J. 2010. Microbial community dynamics in a seasonally anoxic fjord: Saanich Inlet, British Columbia. Environ. Microbiol., 12:172-191.

Zhao, S., Burki, F., Brate, J., Keeling, P. J., Klaveness, D. \& Shalchian-Tabrizi, K. 2012. Collodictyon-An ancient lineage in the tree of eukaryotes. Mol. Biol. Evol., 29:15571568.

\section{FIGURE LEGENDS}

Fig. 1. "Small animals" drawn by Louis Jablot (Jablot 1718); one of the first illustrations of protists.

Fig. 2. Photos illustrating field protistology research. A. Collection of water samples in Bamfield, Pacific west coast of Canada. B. Oceanographic research vessel, Mirai (Japan Agency for Marine-Earth Science and Technology, JAMSTEC) C-D. Water samples are collected in the north western Pacific Ocean via a Niskin bottles carousel system. E. Soil samples are collected in the Swiss Alps to assess the patterns of testate amoeba diversity along an altitudinal gradient. F. Insects are collected in order to assess their parasitic protist diversity (Ecuadorian forest).

This article is protected by copyright. All rights reserved. 


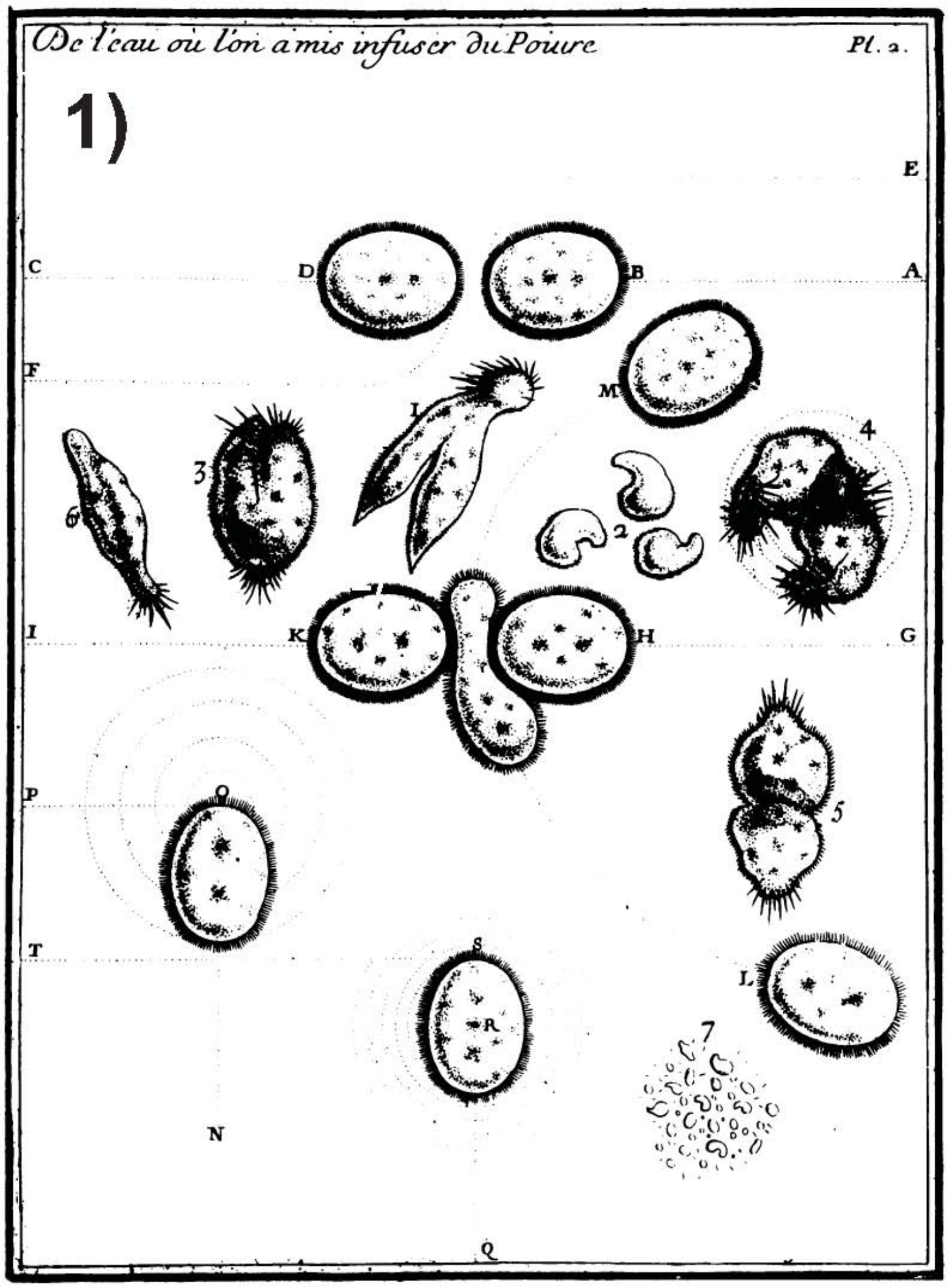

This article is protected by copyright. All rights reserved. 

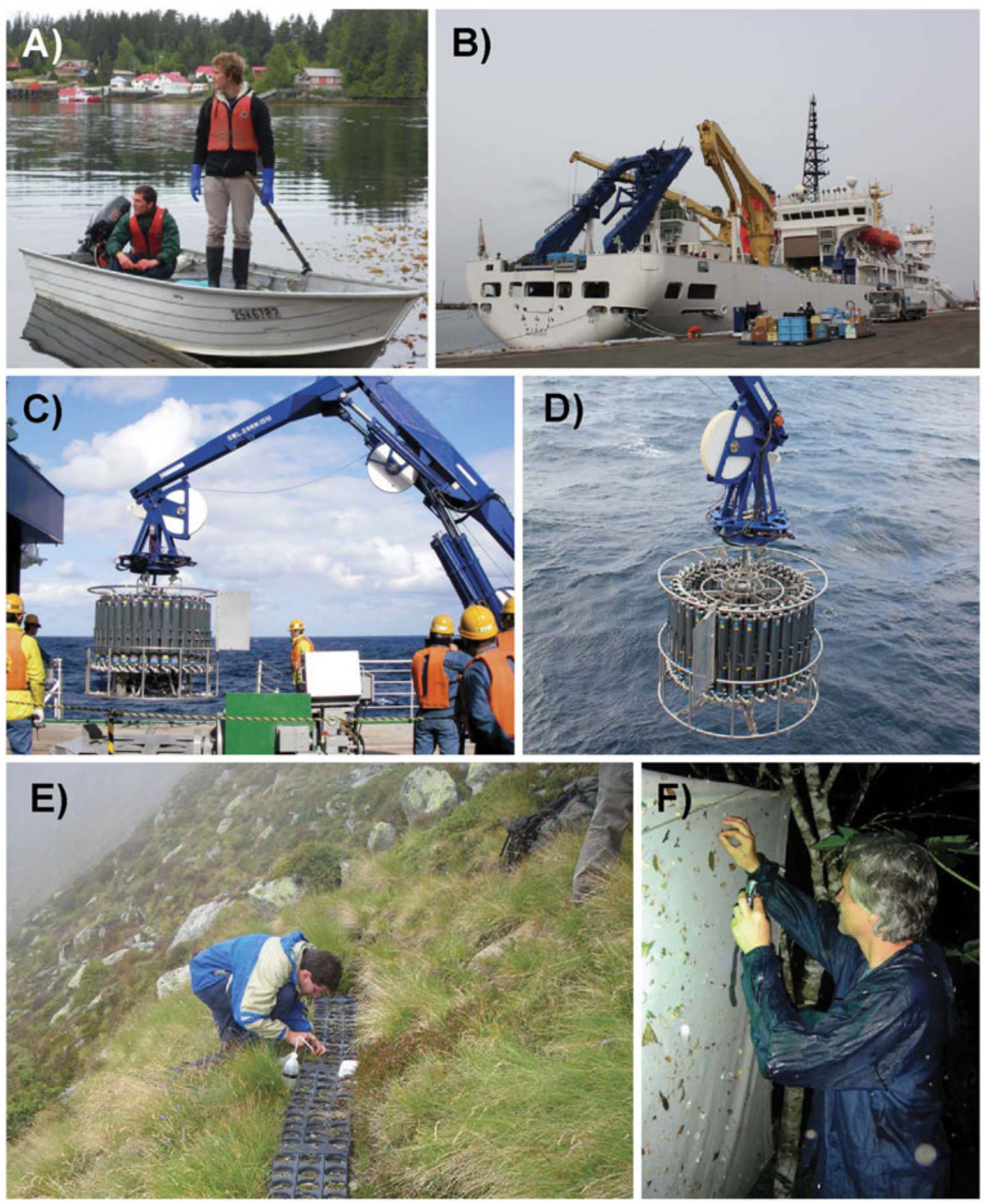

This article is protected by copyright. All rights reserved. 